\title{
PELAKSANAAN TANGGUNG JAWAB SOSIAL DAN LINGKUNGAN PERUSAHAAN BERDASARKAN UNDANG-UNDANG NOMOR 40 TAHUN 2007 UNTUK MENINGKATKAN KESEJAHTERAAN MASYARAKAT KECAMATAN RUMBAI PESISIR KOTA PEKANBARU*
}

\author{
Andrew Shandy Utama \\ Prodi S1 Ilmu Hukum Fakultas Hukum, Universitas Lancang Kuning, Pekanbaru \\ e-mail: andrew.fh.unilak@gmail.com
}

\begin{abstract}
One of the goals of the state as mandated by the 1945 Constitution of the Republic of Indonesia is to improve the welfare of the people. Based on Article 74 Paragraph (1) of Law Number 40 of 2007, it is affirmed that companies that carry out their business activities in the field of natural resources and / or fields related to natural resources must carry out social and environmental responsibilities. How is the implementation of the corporate social and environmental responsibilities based on Law Number 40 of 2007 to improve the welfare of the community of Rumbai Pesisir Subdistrict of Pekanbaru City? The research method used in this research is socio-legal research. The results of this research that the corporate social and environmental responsibility programs on the community economy that have been carried out by PT Chevron Pacific Indonesia are called Local Business Development. The corporate social and environmental responsibility program for the community economy that has been carried out by PT Asia Forestama Raya, namely the creation of traditional markets managed by the community. The conclusion is that the government and the community can utilize the corporate social and environmental responsibility programs as an alternative source of business capital to improve the economy and welfare of the people in the Rumbai Pesisir Subdistrict of Pekanbaru City.
\end{abstract}

Keywords: Corporate, Social and Environmental Responsibility, Community Welfare

\begin{abstract}
Abstrak
Salah satu tujuan negara sebagaimana yang diamanatkan oleh Undang-Undang Dasar Negara Republik Indonesia Tahun 1945 adalah meningkatkan kesejahteraan masyarakat. Berdasarkan Pasal 74 Ayat (1) Undang-Undang Nomor 40 Tahun 2007 ditegaskan bahwa perusahaan yang menjalankan kegiatan usahanya di bidang sumber daya alam dan/atau bidang yang berkaitan dengan sumber daya alam wajib melaksanakan tanggung jawab sosial dan lingkungan. Bagaimanakah pelaksanaan tanggung jawab sosial dan lingkungan perusahaan berdasarkan Undang-Undang Nomor 40 Tahun 2007 untuk meningkatkan kesejahteraan masyarakat Kecamatan Rumbai Pesisir Kota Pekanbaru? Metode penelitian yang digunakan dalam penelitian ini adalah penelitian hukum sosiologis. Hasil dari penelitian ini bahwa program tanggung jawab sosial dan lingkungan perusahaan terhadap perekonomian masyarakat yang telah dilaksanakan oleh PT Chevron Pasifik Indonesia bernama Local Business Development. Program tanggung jawab sosial dan lingkungan perusahaan terhadap perekonomian masyarakat yang telah dilaksanakan oleh PT Asia Forestama Raya yaitu pembuatan pasar tradisional yang dikelola oleh masyarakat. Kesimpulannya adalah pemerintah maupun masyarakat dapat memanfaatkan program tanggung jawab sosial dan lingkungan perusahaan sebagai sumber alternatif permodalan usaha untuk meningkatkan perekonomian dan kesejahteraan masyarakat di Kecamatan Rumbai Pesisir Kota Pekanbaru.
\end{abstract}

Kata Kunci: Perusahaan, Tanggung Jawab Sosial dan Lingkungan, Kesejahteraan Masyarakat

\footnotetext{
* Naskah diterima: 09 Agustus 2018, direvisi: 22 Agustus 2018, disetujui untuk terbit: 24 September 2018
} 
Andrew Shandy Utama: Pelaksanaan Tanggung Jawab Sosial Dan Lingkungan...

\section{PENDAHULUAN}

Salah satu tujuan negara sebagaimana yang diamanatkan oleh Undang-Undang Dasar Negara Republik Indonesia Tahun 1945 adalah meningkatkan kesejahteraan masyarakat. Di dalam Pembukaan Undang-Undang Dasar Negara Republik Indonesia Tahun 1945 tercantum empat tujuan dari didirikannya negara, yaitu sebagai berikut:

1. Melindungi segenap bangsa Indonesia dan seluruh tumpah darah Indonesia.

2. Memajukan kesejahteraan umum.

3. Mencerdaskan kehidupan bangsa.

4. Ikut melaksanakan ketertiban dunia yang berdasarkan kemerdekaan, perdamaian abadi, dan keadilan sosial.

Dalam rangka meningkatkan

kesejahteraan masyarakat, Pemerintah Republik Indonesia telah membuat berbagai kebijakan, khususnya di bidang perekonomian. Hal ini dikarenakan untuk dapat meningkatkan kesejahteraan masyarakat harus dimulai dengan peningkatan perekonomian masyarakat terlebih dahulu. Sebagaimana diketahui, salah satu permasalahan utama yang menghambat masyarakat untuk memulai usaha yaitu dalam hal permodalan (Utama \& Sartika, Peran Strategis Bank Syariah sebagai Sumber Pembiayaan Alternatif bagi Usaha Mikro di Indonesia Berdasarkan Undang-Undang Nomor 21 Tahun 2008, 2017). Oleh karena itu, pemerintah diharapkan mampu mengeluarkan kebijakan di bidang perekonomian untuk memberikan modal usaha kepada masyarakat.
Sebenarnya, pemerintah telah mengeluarkan berbagai kebijakan di bidang perekonomian untuk meningkatkan kesejahteraan masyarakat. Salah satu program unggulan pemerintah melalui Kementerian Koordinator Perekonomian Republik Indonesia adalah Kredit Usaha Rakyat (KUR). Akan tetapi, terbatasnya jumlah anggaran dana yang dimiliki oleh negara sehingga pemerintah belum mampu untuk menjangkau seluruh lapisan masyarakat hingga ke daerah-daerah. Untuk itu, pemerintah harus mampu mencarikan solusi permodalan usaha bagi masyarakat dalam rangka meningkatkan perekonomian masyarakat.

Untuk membantu permodalan usaha bagi masyarakat, pemerintah sebenarnya dapat melibatkan pihak ketiga, yaitu perusahaan-perusahaan swasta yang beroperasi di Indonesia. Sejak tahun 2007, dengan disahkannya Undang-Undang Nomor 40 Tahun 2007 tentang Perseroan Terbatas, perusahaan-perusahaan terutama perusahaan yang menjalankan kegiatan usahanya di bidang sumber daya alam dan/atau bidang yang berkaitan dengan sumber daya alam wajib melaksanakan tanggung jawab sosial dan lingkungan.

Tujuan utama dari sebuah perusahaan adalah untuk mendapatkan keuntungan yang sebesar-besarnya. Hal ini merupakan tanggung jawab para pengurus perusahaan kepada pemegang saham sebagai pemilik dari perusahaan tersebut. Inilah dasar filosofis didirikannya sebuah perusahaan. Namun demikian, kegiatan operasional perusahaan dalam rangka memaksimalisasi keuntungannya seringkali memberikan 
dampak yang negatif terhadap masyarakat dan lingkungan di sekitarnya, seperti terjadinya polusi dan berbagai kerusakan lingkungan. Permasalahan tersebut merupakan dasar lahirnya konsep tanggung jawab sosial dan lingkungan perusahaan (Fahmi, Tanggung Jawab Sosial Perusahaan; dari Tanggung Jawab Moral Menuju Tanggung Jawab Hukum yang Berkeadilan Sosial, 2011).

Tanggung jawab sosial dan lingkungan merupakan kewajiban perusahaan yang dianggarkan dan diperhitungkan sebagai biaya perusahaan. Ketentuan ini bertujuan untuk menciptakan hubungan yang harmonis antara perusahaan dengan masyarakat, khususnya masyarakat yang bertempat tinggal di sekitar area perusahaan. Oleh karena itu, pemerintah maupun masyarakat dapat memanfaatkan program tanggung jawab sosial dan lingkungan perusahaan sebagaimana yang diamanatkan oleh Undang-Undang Nomor 40 Tahun 2007 tentang Perseroan Terbatas untuk dapat meningkatkan perekonomian masyarakat, termasuk masyarakat di Kecamatan Rumbai Pesisir Kota Pekanbaru.

Dari latar belakang masalah yang telah dijelaskan di atas, maka permasalahan yang dibahas dalam penelitian ini adalah bagaimanakah pelaksanaan tanggung jawab sosial dan lingkungan perusahaan berdasarkan Undang-Undang Nomor 40 Tahun 2007 tentang Perseroan Terbatas untuk meningkatkan kesejahteraan masyarakat Kecamatan Rumbai Pesisir Kota Pekanbaru?

\section{METODE PENELITIAN}

Penelitian hukum adalah suatu kegiatan ilmiah yang didasarkan pada metode, sistematika, dan pemikiran tertentu, yang bertujuan untuk mempelajari satu atau beberapa gejala hukum tertentu dengan jalan menganalisanya (Soekanto, 2007). Metode penelitian yang digunakan dalam penelitian ini adalah penelitian hukum sosiologis. Penelitian hukum sosiologis adalah suatu penelitian yang dilakukan dengan cara observasi untuk menjelaskan permasalahan hukum yang terjadi di masyarakat. Dalam penelitian hukum sosiologis, hal yang diteliti adalah data primer (Amiruddin \& Asikin, 2006).

Sumber data yang digunakan dalam penelitian ini adalah data primer dan data sekunder. Data primer yaitu data yang diperoleh langsung dari hasil observasi dan wawancara di lokasi penelitian; sedangkan data sekunder yaitu data yang diperoleh dari jurnal-jurnal ilmiah, literatur hukum, dan peraturan perundang-undangan. Teknik pengumpulan data yang digunakan dalam penelitian ini adalah observasi, wawancara, dan studi kepustakaan. Teknik analisis data yang digunakan dalam penelitian ini adalah analisis kualitatif.

\section{HASIL DAN PEMBAHASAN}

Berdasarkan Pasal 1 Undang-Undang Nomor 40 Tahun 2007 dijelaskan bahwa perseroan terbatas (perusahaan) adalah badan hukum yang merupakan persekutuan modal, didirikan berdasarkan perjanjian, melakukan kegiatan usaha dengan modal dasar yang seluruhnya terbagi dalam saham, dan memenuhi 
Andrew Shandy Utama: Pelaksanaan Tanggung Jawab Sosial Dan Lingkungan...

persyaratan yang ditetapkan oleh undangundang dan peraturan pelaksanaannya.

Pengaturan mengenai tanggung jawab sosial dan lingkungan perusahaan tidak terlepas dari dampak negatif yang ditimbulkan dari beroperasinya suatu kegiatan bisnis yang dijalankan oleh perusahaan. Oleh karena itu, kewajiban untuk melaksanakan tanggung jawab sosial dan lingkungan perusahaan mulai diatur di dalam berbagai peraturan perundangundangan, termasuk Undang-Undang Nomor 40 Tahun 2007 tentang Perseroan Terbatas (Sunaryo, 2015).

Pada tahun 2007, terjadi perubahan yang signifikan mengenai tanggung jawab sosial dan lingkungan perusahaan dalam sistem hukum nasional di Indonesia setelah disahkannya Undang-Undang Nomor 40 Tahun 2007 tentang Perseroan Terbatas. Pengaturan mengenai tanggung jawab sosial dan lingkungan perusahaan bertujuan untuk mewujudkan pembangunan ekonomi berkelanjutan guna meningkatkan kualitas kehidupan dan lingkungan yang bermanfaat bagi perusahaan itu sendiri, komunitas setempat, dan masyarakat pada umumnya (Utama \& Rizana, Implementasi Corporate Social Responsibility PT Riau Crumb Rubber Factory terhadap Masyarakat Kelurahan Sri Meranti Kota Pekanbaru, 2017).

Ketentuan mengenai tanggung jawab sosial dan lingkungan perusahaan diatur secara tegas dalam Pasal 74 UndangUndang Nomor 40 Tahun 2007 tentang Perseroan Terbatas. Berdasarkan Pasal 74 Ayat (1) Undang-Undang Nomor 40
Tahun 2007 tentang Perseroan Terbatas ditegaskan bahwa perusahaan yang menjalankan kegiatan usahanya di bidang sumber daya alam dan/atau bidang yang berkaitan dengan sumber daya alam wajib melaksanakan tanggung jawab sosial dan lingkungan.

Perusahaan yang menjalankan kegiatan usahanya di bidang sumber daya alam dan/atau bidang yang berkaitan dengan sumber daya alam dalam mengelola kekayaan alam untuk mencari keuntungan bisnis yang sebesar-besarnya di satu sisi dapat mempengaruhi kehidupan masyarakat lokal yang sangat bergantung pada hasil alam maupun kelestarian lingkungan hidup yang ada di sekitarnya, sehingga perusahaan memiliki hubungan timbal balik dengan masyarakat dan lingkungan. Oleh karena itu, perusahaan yang menjalankan kegiatan usahanya di bidang sumber daya alam dan/atau bidang yang berkaitan dengan sumber daya alam diwajibkan untuk melaksanakan tanggung jawab sosial dan lingkungan dalam rangka meningkatkan kesejahteraan masyarakat dan menjaga kelestarian lingkungan (Fahmi, Pergeseran Tanggung Jawab Sosial Perseroan; Dari Tanggung Jawab Moral ke Tanggung Jawab Hukum, 2015).

Undang-Undang Nomor 40 Tahun 2007 tentang Perseroan Terbatas telah merubah paradigma tanggung jawab sosial dan lingkungan perusahaan, dari bersifat sukarela yang berdasarkan moral menjadi kewajiban hukum bagi perusahaan (Firdaus, 2010).

Sebagai peraturan pelaksana dari Pasal 74 Undang-Undang Nomor 40 Tahun 2007 
tentang Perseroan Terbatas tersebut, pemerintah mengesahkan Peraturan Pemerintah Nomor 47 Tahun 2012 tentang Tanggung Jawab Sosial dan Lingkungan Perseroan Terbatas.

Di dalam Peraturan Pemerintah Nomor 47 Tahun 2012 tentang Tanggung Jawab Sosial dan Lingkungan Perseroan Terbatas diatur mengenai:

1. Tanggung jawab sosial dan lingkungan dilaksanakan oleh perusahaan yang menjalankan kegiatan usahanya di bidang sumber daya alam dan/atau bidang yang berkaitan dengan sumber daya alam.

2. Tanggung jawab sosial dan lingkungan dilaksanakan di dalam maupun di luar area perusahaan.

3. Tanggung jawab sosial dan lingkungan dilaksanakan berdasarkan rencana kerja tahunan perusahaan, yang memuat rencana kegiatan dan anggaran yang dibutuhkan untuk pelaksanaannya.

4. Pelaksanaan tanggung jawab sosial dan lingkungan disusun dengan memperhatikan kepatutan dan kewajaran.

5. Pelaksanaan tanggung jawab sosial dan lingkungan dimuat dalam laporan tahunan perusahaan untuk dipertanggungjawabkan kepada Rapat Umum Pemegang Saham.

6. Sanksi bagi perusahaan yang tidak melaksanakan tanggung jawab sosial dan lingkungan.

7. Perusahaan yang telah melaksanakan tanggung jawab sosial dan lingkungan dapat diberikan penghargaan oleh pemerintah.

Pengaturan mengenai tanggung jawab sosial perusahaan dari pemerintah yang merespon kebutuhan stakeholders dan bersifat sustainable development dapat dijadikan pedoman bagi perusahaan sebagai pelaku usaha sebagai wujud dari prinsip good corporate governance untuk mencapai keadilan dan kesejahteraan masyarakat (Risa, 2018).

Pelaksanaan tanggung jawab sosial dan lingkungan perusahaan diharapkan dapat menjaga hubungan baik antara pihak perusahaan dengan masyarakat yang bertempat tinggal di sekitar area perusahaan, agar kegiatan operasional perusahaan dapat berjalan dengan lancar tanpa adanya gangguan dari masyarakat. Selain itu, manfaat lainnya bagi perusahaan dengan dilaksanakannya tanggung jawab sosial perusahaan yaitu sebagai berikut (Untung, 2009):

1. Mempertahankan dan mendongkrak reputasi serta citra merek perusahaan.

2. Mendapatkan lisensi untuk beroperasi secara sosial.

3. Mereduksi risiko bisnis perusahaan.

4. Melebarkan akses sumber daya bagi operasional usaha.

5. Membuka peluang pasar yang lebih luas.

6. Mereduksi biaya.

7. Memperbaiki hubungan dengan stakeholders.

8. Memperbaiki hubungan dengan regulator.

9. Meningkatkan semangat dan produktivitas karyawan. 
Andrew Shandy Utama: Pelaksanaan Tanggung Jawab Sosial Dan Lingkungan...

Lahirnya Peraturan Daerah Provinsi Riau Nomor 6 Tahun 2012 tentang Tanggung Jawab Sosial Perusahaan di Provinsi Riau semakin memperkokoh landasan hukum mengenai tanggung jawab sosial dan lingkungan perusahaan bagi perusahaan-perusahaan yang beroperasi di wilayah Provinsi Riau, termasuk di Kota Pekanbaru. Peraturan daerah tersebut mengatur mengenai pelaksanaan tanggung jawab sosial perusahaan kepada masyarakat (Utama \& Rizana, Upaya Hukum Masyarakat Kecamatan Rumbai Pekanbaru dalam Pemenuhan Hak Masyarakat Melalui Program Corporate Social Responsibility (CSR), 2018).

Berdasarkan Pasal 10 Peraturan Daerah Provinsi Riau Nomor 6 Tahun 2012 tentang Tanggung Jawab Sosial Perusahaan di Provinsi Riau disebutkan bahwa program tanggung jawab sosial perusahaan dapat berbentuk pemberdayaan masyarakat dan/atau kemitraan dan bina lingkungan dan/atau investasi dan/atau sumbangan/donasi, dan/atau promosi. Selanjutnya, berdasarkan Pasal 11 Peraturan Daerah Provinsi Riau Nomor 6 Tahun 2012 tentang Tanggung Jawab Sosial Perusahaan di Provinsi Riau disebutkan bahwa bidang kerja tanggung jawab sosial perusahaan dapat dijalankan pada bidang pendidikan, kesehatan, infrastruktur, olahraga dan seni budaya, sosial dan keagamaan, pelestarian lingkungan hidup, usaha ekonomi kerakyatan, pemberdayaan masyarakat adat, serta bidang kerja lainnya yang secara nyata memberikan dampak peningkatan kualitas masyarakat.
Ketentuan pada Pasal 10 Peraturan Daerah Provinsi Riau Nomor 6 Tahun 2012 tentang Tanggung Jawab Sosial Perusahaan di Provinsi Riau mengenai pemberdayaan masyarakat dan Pasal 11 Peraturan Daerah Provinsi Riau Nomor 6 Tahun 2012 tentang Tanggung Jawab Sosial Perusahaan di Provinsi Riau mengenai usaha ekonomi kerakyatan seharusnya dapat dimanfaatkan oleh pemerintah maupun masyarakat sebagai sumber alternatif permodalan usaha untuk meningkatkan perekonomian masyarakat di Kota Pekanbaru, terutama masyarakat Kecamatan Rumbai Pesisir.

Kecamatan Rumbai Pesisir merupakan salah satu kecamatan yang berada di pinggir Kota Pekanbaru, sehingga jarang tersentuh pembangunan kota. Di Kecamatan Rumbai Pesisir Kota Pekanbaru terdapat tiga perusahaan yang menjalankan kegiatan usahanya di bidang sumber daya alam dan/atau bidang yang berkaitan dengan sumber daya alam, yaitu PT Chevron Pasifik Indonesia di Kelurahan Lembah Damai yang bergerak di bidang pertambangan minyak bumi, PT Asia Forestama Raya di Kelurahan Limbungan yang bergerak di bidang industri kayu lapis, dan PT Surya Inti Raya di Kelurahan Tebing Tinggi Okura yang bergerak di bidang perkebunan kelapa sawit.

Di Kabupaten Pelalawan, program tanggung jawab sosial dan lingkungan perusahaan yang dilaksanakan oleh PT Riau Andalan Pulp and Paper manfaatnya dapat dirasakan langsung oleh masyarakat. Adapun program tanggung jawab sosial 
perusahaan terhadap peningkatan perekonomian masyarakat yang telah dilaksanakan oleh PT Riau Andalan Pulp and Paper yaitu pemberian bantuan bibit kepada masyarakat yang berwirausaha di bidang pertanian, perkebunan, dan perikanan; pemberian bantuan dana kepada masyarakat yang berwirausaha inline dengan kegiatan perusahaan seperti menjual pupuk tanaman maupun offline dengan kegiatan perusahaan seperti menjual makanan khas daerah; serta pemberian pelatihan las, otomotif, dan menjahit kepada generasi muda sebagai bekal dalam memasuki dunia kerja (Utama, Implementasi Corporate Social Responsibility PT Riau Andalan Pulp and Paper terhadap Masyarakat di Kabupaten Pelalawan, 2018).

Perusahaan memiliki peran strategis dalam mendorong pertumbuhan tingkat kesejahteraan masyarakat. Hal tersebut dilakukan dengan menciptakan lapangan pekerjaan dan memberikan bantuanbantuan lainnya kepada negara maupun masyarakat melalui tanggung jawab sosial dan lingkungan perusahaan. Undangundang mewajibkan perusahaan untuk melaksanakannya (Pujiyono, Wiwoho, \& Triyanto, 2016).

Berdasarkan hasil wawancara dengan Manajer Humas PT Chevron Pasifik Indonesia dijelaskan bahwa program tanggung jawab sosial perusahaan terhadap peningkatan perekonomian masyarakat yang diprogramkan oleh PT Chevron Pasifik Indonesia bernama Local Business Development. Kegiatan-kegiatan yang telah dilaksanakannya yaitu pelatihan kewirausahaan untuk generasi muda, pemberian bantuan bibit ikan dan benih buah-buahan untuk masyarakat yang berprofesi sebagai petani, serta pengerjaan proyek-proyek kecil di area perusahaan untuk kelompok usaha masyarakat. Program tanggung jawab sosial dan lingkungan perusahaan yang dilaksanakan oleh PT Chevron Pasifik Indonesia tersebut manfaatnya dapat dirasakan langsung oleh masyarakat Kecamatan Rumbai Pesisir Kota Pekanbaru.

Berdasarkan hasil wawancara dengan Manajer Humas PT Asia Forestama Raya dijelaskan bahwa salah satu program tanggung jawab sosial perusahaan terhadap peningkatan perekonomian masyarakat yang telah dilaksanakan oleh PT Asia Forestama Raya yaitu penyediaan sebidang tanah milik perusahaan beserta bahan baku berupa kayu untuk pembuatan pasar tradisional yang dikelola oleh masyarakat. Program tanggung jawab sosial dan lingkungan perusahaan yang dilaksanakan oleh PT Asia Forestama Raya tersebut manfaatnya dapat dirasakan langsung oleh masyarakat Kecamatan Rumbai Pesisir Kota Pekanbaru.

Sementara itu, berdasarkan hasil wawancara dengan salah seorang tokoh masyarakat di Kecamatan Rumbai Pesisir Kota Pekanbaru dijelaskan bahwa PT Surya Inti Raya tidak ada melaksanakan program tanggung jawab sosial dan lingkungan perusahaan untuk meningkatkan perekonomian masyarakat yang bertempat tinggal di sekitar area perusahaan. Akan tetapi, PT Surya Inti Raya telah membuka akses jalan baru 
Andrew Shandy Utama: Pelaksanaan Tanggung Jawab Sosial Dan Lingkungan...

sebagai jalan pintas yang menghubungkan antara Kecamatan Rumbai Pesisir Kota Pekanbaru dengan Kecamatan Tualang Kabupaten Siak dan mengizinkan masyarakat Kecamatan Rumbai Pesisir Kota Pekanbaru yang bekerja maupun berdagang di Kecamatan Tualang Kabupaten Siak untuk melewati jalan yang berada di dalam area perusahaan tersebut.

Banyak perusahaan yang tidak mau membuat dan melaksanakan programprogram tanggung jawab sosial dan lingkungan perusahaan karena hal tersebut dianggap sebagai biaya pengeluaran perusahaan. Tanggung jawab sosial dan lingkungan perusahaan memang tidak memberikan keuntungan secara materi dalam waktu yang singkat, tetapi lebih kepada investasi jangka panjang yang keuntungannya akan dinikmati oleh perusahaan di masa yang akan datang. Oleh karena itu, tanggung jawab sosial dan lingkungan perusahaan akan lebih tepat apabila dikategorikan sebagai investasi jangka panjang sebuah perusahaan (Yetti, 2007).

Terhadap pelaksanaan tanggung jawab sosial perusahaan, secara internasional, perusahaan dikelompokkan menjadi empat kelompok yaitu sebagai berikut (Untung, 2009):

\section{Black Company}

Pihak perusahaan yang termasuk Balck Company dalam menjalankan kegiatan usahanya lebih mengutamakan kepentingan bisnis untuk mencari keuntungan yang sebesar-sebesarnya tanpa memperhatikan keadaan masyarakat dan lingkungan di sekitarnya.

\section{Red Company}

Pihak perusahaan yang termasuk Red Company telah mulai melaksanakan tanggung jawab sosial perusahaan terhadap masyarakat yang bertempat tinggal di sekitar lokasi perusahaan, tetapi tanggung jawab sosial perusahaan dianggap sebagai biaya pengeluaran yang dapat mengurangi keuntungan perusahaan.

3. Blue Company

Pihak perusahaan yang termasuk Blue Company melaksanakan tanggung jawab sosial perusahaan terhadap masyarakat yang bertempat tinggal di sekitar lokasi perusahaan dengan tujuan untuk menjaga hubungan baik antara pihak perusahaan dengan masyarakat sebagai investasi.

\section{Green Company}

Pihak perusahaan yang termasuk Green Company menempatkan tanggung jawab sosial perusahaan sebagai salah satu bagian dari inti bisnisnya karena tanggung jawab sosial perusahaan merupakan kebutuhan yang wajib untuk dilaksanakan dalam menjalankan kegiatan usahanya.

Tanggung jawab sosial dan lingkungan perusahaan merupakan komitmen dunia bisnis untuk berkontribusi dalam pengembangan ekonomi yang berkelanjutan dengan memperhatikan tanggung jawab perusahaan serta menitikberatkannya pada aspek ekonomi, sosial, dan lingkungan. Konsep pengelolaan perusahaan yang baik menggunakan pendekatan triple bottom 
line yang mengintegrasikan tiga prinsip dari pembangunan berkelanjutan, yaitu tujuan perusahaan dalam mendapatkan keuntungan, perlindungan terhadap lingkungan, dan mewujudkan keadilan sosial. Ketiganya harus ada dalam kebijakan perusahaan (Fahmi, Tanggung Jawab Sosial Perusahaan; dari Tanggung Jawab Moral Menuju Tanggung Jawab Hukum yang Berkeadilan Sosial, 2011).

Keberhasilan suatu daerah dalam meningkatkan kesejahteraan masyarakatnya dapat terwujud apabila seluruh komponen masyarakat ikut dilibatkan, termasuk partisipasi yang nyata dari perusahaan yang beroperasi di daerah tersebut (Siregar \& Ihsan, 2013). Program tanggung jawab sosial dan lingkungan perusahaan sebenarnya bukan hanya bermanfaat bagi masyarakat, melainkan juga bermanfaat bagi perusahaan untuk membentuk citra positif perusahaan apabila dikemas dengan publikasi yang tepat (Yetti, 2007).

Berdasarkan Pasal 74 Ayat (3) Undang-Undang Nomor 40 Tahun 2007 tentang Perseroan Terbatas disebutkan bahwa perusahaan yang tidak melaksanakan tanggung jawab sosial dan lingkungan dikenai sanksi sesuai dengan ketentuan peraturan perundang-undangan. Artinya, sanksi terhadap perusahaan yang tidak melaksanakan tanggung jawab sosial dan lingkungan perusahaan ada pada undang-undang yang lain, yaitu UndangUndang Nomor 25 Tahun 2007 tentang Penanaman Modal. Berdasarkan Pasal 34 Undang-Undang Nomor 25 Tahun 2007 tentang Penanaman Modal ditegaskan bahwa perusahaan yang tidak memenuhi kewajibannya melaksanakan tanggung jawab sosial perusahaan dapat dikenai sanksi administratif oleh instansi atau lembaga yang berwenang berupa:

1. Peringatan tertulis.

2. Pembatasan kegiatan usaha.

3. Pembekuan kegiatan usaha dan/atau fasilitas penanaman modal.

4. Pencabutan kegiatan usaha dan/atau fasilitas penanaman modal.

Undang-undang sebaiknya tidak hanya mengatur mengenai sanksi bagi perusahaan yang tidak melaksanakan tanggung jawab sosial perusahaan, tetapi juga harus diatur mengenai reward dalam bentuk insentif pajak maupun bentukbentuk lainnya kepada perusahaan yang telah melaksanakan tanggung jawab sosial perusahaan kepada masyarakat dengan optimal (Risa, 2018).

\section{SIMPULAN}

Berdasarkan Pasal 74 Ayat (1) Undang-Undang Nomor 40 Tahun 2007 ditegaskan bahwa perusahaan yang menjalankan kegiatan usahanya di bidang sumber daya alam dan/atau bidang yang berkaitan dengan sumber daya alam wajib melaksanakan tanggung jawab sosial dan lingkungan. Ketentuan tersebut seharusnya dapat dimanfaatkan oleh pemerintah dan masyarakat sebagai sumber alternatif permodalan usaha untuk meningkatkan perekonomian masyarakat di Kecamatan Rumbai Pesisir Kota Pekanbaru. Program tanggung jawab sosial perusahaan terhadap perekonomian masyarakat yang telah dilaksanakan oleh PT Chevron Pasifik Indonesia bernama Local Business 
Andrew Shandy Utama: Pelaksanaan Tanggung Jawab Sosial Dan Lingkungan...

Development, yaitu pelatihan kewirausahaan, pemberian bantuan bibit ikan dan benih buah-buahan, serta pengerjaan proyek kecil untuk kelompok usaha masyarakat. Program tanggung jawab sosial perusahaan terhadap perekonomian masyarakat yang telah dilaksanakan oleh PT Asia Forestama Raya yaitu penyediaan sebidang tanah milik perusahaan beserta bahan baku berupa kayu untuk pembuatan pasar tradisional yang dikelola oleh masyarakat. Keberhasilan suatu daerah dalam meningkatkan kesejahteraan masyarakatnya dapat terwujud apabila seluruh komponen masyarakat ikut dilibatkan, termasuk partisipasi yang nyata dari perusahaan yang beroperasi di daerah tersebut.

\section{UCAPAN TERIMA KASIH}

Telah selesainya penelitian ini tentunya tidak terlepas karena dukungan serta bantuan dari berbagai pihak. Oleh karena itu, penulis sampaikan rasa terima kasih yang sebesar-besarnya kepada Rektor Universitas Lancang Kuning Dr. Hj. Hasnati, S.H.,M.H. dan Dekan Fakultas Hukum Universitas Lancang Kuning Dr. H. Iriansyah, S.H., M.H., yang telah memberikan kesempatan kepada penulis untuk melaksanakan penelitian.

\section{DAFTAR PUSTAKA}

Amiruddin, \& Asikin, Z, 2006, Pengantar Metode Penelitian Hukum, Rajawali Pers, Jakarta.

Fahmi, 2011, Tanggung Jawab Sosial Perusahaan; dari Tanggung Jawab Moral Menuju Tanggung Jawab
Hukum yang Berkeadilan Sosial. Respublica, 16-31.

Fahmi, 2015, Pergeseran Tanggung Jawab Sosial Perseroan; Dari Tanggung Jawab Moral ke Tanggung Jawab Hukum, FH UII Press, Yogyakarta.

Firdaus, 2010, Corporate Social Responsibility; Transformasi Moral ke dalam Hukum dalam Membangun Kesejahteraan Masyarakat. Ilmu Hukum, 16-30.

Pujiyono, Wiwoho, J., \& Triyanto, 2016, Model Pertanggungjawaban Hukum Pelaksanaan Corporate Social Responsibility (CSR) untuk Meningkatkan Kesejahteraan Masyarakat. Yustisia, 41-51.

Risa, Y, 2018, Pelaksanaan Corporate Social Responsibility pada PT Perkebunan Nusantara VI Unit Usaha Danau Kembar. Cendekia Hukum, 188-197.

Siregar, L., \& Ihsan, R, 2013, Penerapan Ketentuan Corporate Social Responsibility (CSR) pada Perusahaan Swasta. Ius, 220-234.

Soekanto, S, 2007, Pengantar Penelitian Hukum. Jakarta: UI Press.

Sunaryo, 2015, Corporate Social Responsibility (CSR) dalam Perspektif Pembangunan Berkelanjutan. Masalah Masalah Hukum, 26-33.

Untung, H. B, 2009, Corporate Social Responsibility, Sinar Grafika, Jakarta.

Utama, A. S, 2018, Implementasi Corporate Social Responsibility PT Riau Andalan Pulp and Paper 
Jurnal Cendekia Hukum: Vol. 4, No 1, September 2018

terhadap Masyarakat di Kabupaten

Pelalawan. Selat, 123-133.

Utama, A. S., \& Rizana, 2017, Implementasi Corporate Social Responsibility PT Riau Crumb Rubber Factory terhadap Masyarakat Kelurahan Sri Meranti Kota Pekanbaru. Novelty, 173-186.

Utama, A. S., \& Rizana, 2018, Upaya Hukum Masyarakat Kecamatan Rumbai Pekanbaru dalam Pemenuhan Hak Masyarakat Melalui Program Corporate Social Responsibility (CSR). Melayunesia Law, 79-93.

Utama, A. S., \& Sartika, D, 2017, Peran Strategis Bank Syariah sebagai Sumber Pembiayaan Alternatif bagi Usaha Mikro di Indonesia Berdasarkan Undang-Undang Nomor 21 Tahun 2008. Al-Amwal, 58-72.

Yetti, 2007, Tanggung Jawab Perusahaan terhadap Sosial dan Lingkungan Berdasarkan Undang-Undang Nomor 40 Tahun 2007 tentang Perseroan Terbatas. Respublica, 113118. 